\title{
The Effect of Blood and Milk Serum Zinc Concentration on Milk Somatic Cell Count in Dairy Cows
}

\author{
Ivana DAVIDOV*, Mihajlo ERDELJAN, Miodrag RADINOVIĆ, Zorana KOVAČEVIĆ and Željka \\ JURAKIĆ \\ University of Novi Sad, Faculty of Agriculture, Department of Veterinary Medicine, Trg Dositeja \\ Obradovića 8, 21000 Novi Sad, Serbia \\ *corresponding author: ivana.davidov@polj.edu.rs
}

Bulletin UASVM Veterinary Medicine 73(2) / 2016,

Print ISSN 1843-5270; Electronic ISSN 1843-5378

DOI:10.15835/buasvmcn-vm: 10741

\begin{abstract}
The objective of this study was to evaluate the effect of blood and milk zinc concentration on milk somatic cell count and occurrence of subclinical mastitis cases. The study was performed on thirty Holstein cows approximate same body weight, ages 3 to 5 years, with equally milk production. Blood samples were taken after morning milking from the caudal vein. Milk samples were taken before morning milking. Zinc concentration was determined from blood and milk by inductively coupled plasma mass spectrometry. $37.67 \%$ cows have zinc blood serum concentration below $7 \mu \mathrm{mol} / \mathrm{l}$, and $63.33 \%$ cows have zinc blood serum concentration higher then $13 \mu \mathrm{mol} / \mathrm{l}$. Also $30 \%$ cows have somatic cell count lower then $400.000 / \mathrm{ml}$ which indicate absence of subclinical mastitis, but $70 \%$ cows have somatic cell count higher than $400.000 / \mathrm{ml}$ which indicate subclinical mastitis. Results indicate that cows with level of zinc in blood serum higher then $13 \mu \mathrm{mol} / \mathrm{l}$ have lower somatic cell count. Cows with lower zinc blood serum concentration then $7 \mu \mathrm{mol} / 1$ have high somatic cell count and high incidence of subclinical mastitis. According to results in this research there is no significant effect of milk serum zinc concentration on somatic cell count in dairy cows.
\end{abstract}

Keywords: zinc, cow, milk, somatic cell count

\section{INTRODUCTION}

Zinc as an essential trace element in human and animal nutrition and playing a role in the cell structure or in function of several enzymes. Zinc deficiency can lead to anorexia, poor growth and wound healing and skin problems (Underwood, 1977; Blakeborough et al., 1983). The primary function of zinc is as an antioxidation. He is the micronutritient who has been established as an essential component of the dairy cows diet for maintaining health (Andieu, 2008). Physiological processes in cells, environmental insults and inflammatory responses produce compounds called free radicals. The major free radicals found in biological systems are superoxide, hydrogen peroxide, hydroxyl radical and fatty acid radicals. Free radicals can react with fatty acids in membranes causing membrane instability. Free radicals can eventually kill cells and damage tissues (Spears and Weiss, 2008).

The main concentration of zinc is present in stratum corneum of cow udder ductus papillary's. Ductus papillary's is the primary physical and chemical barrier, preventing penetration of microorganisms into the udder. Between two milking, the circular smooth muscle that surround ductus papillary's slowly contract and closing lumen of ductus papillary's preventing 
penetration of bacteria and preventing bacterial colonization in udder parenchyma (Paulrud, 2005). The penetration of microorganisms into the parenchyma of cow udder is by weakening of the first line of defense, especially the stratum corneum (Davidov et al., 2011).

Knowles et al. (2006) find that cow`s zinc milk serum concentration ranges from 2 to $6 \mathrm{mg} / \mathrm{l}$. Physiology level of zinc blood serum concentration

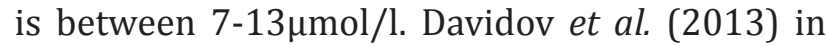
their research find that at first lactating month the mean estimate of zinc blood serum concentration was $12.22 \pm 6.81 \mu \mathrm{mol} / \mathrm{l}$ and at sixth lactating month was $14.25 \pm 8.04 \mu \mathrm{mol} / \mathrm{l}$. Opposite to them, Pechova et al. (2008), find that zinc blood serum concentration was $16.27 \pm 2.77 \mu \mathrm{mol} / \mathrm{l}$. Zinc blood serum concentration can drop by up to $50 \%$ due to high stress, trauma or inflammatory process (Zadak, 2002).

Davidov et al. (2013) in their research find $43.33 \%$ cows with milk somatic cell count over $450.000 / \mathrm{ml}$ in first lactating month. This percent of cows was indicated subclinical mastitis according to somatic cell count. The European Union Directives (92/46CEE and 94/71 CEE) set a limit of 400,000 cells $/ \mathrm{ml}$ for somatic cell count in raw milk. When the initial somatic cell count was high in dairy cows, intake of organically zinc reduced somatic cell count (Barbano et al., 2006). Sharma et al. (2011) showed the importance of somatic cells in the assessment of milk quality and udder health.

The aim of this study was to find the effect of blood and milk serum zinc concentration on milk somatic cell count in dairy cows.

\section{MATERIALS AND METHODS}

\section{Animals}

The study was performed on randomly took thirty Holstein cows in three farms in Vojvodina a region of Serbia. All cows were approximate same body weight, ages 3 to 5 years, in the same phase of lactation, with equally milk production.

\section{Samples}

By applying the principles of asepsis and antisepsis, blood samples were taken after morning milking from caudal vein. Blood samples were taken in vacutainer tube (BD Vacutainer Systems, Preanalytical Solutions UK) with added anticoagulant K3E in quantities of $0.072 \mathrm{ml}$. The samples were gently shaken several times in order to anticoagulant mixes with the blood. Each vacutainer tube was marked with ID number of cow and left at room temperature for 24 hours. After 24 hours the solution was diluted with water and zinc was subsequently determined by inductively coupled plasma mass spectrometry (Perkin Elmer Elan 6100 ICPMS, Massachusetts, USA).

The samples of milk were taken before morning milking from all four quarters of udder. Milk samples were analyzed for somatic cell count by the fluor-optoelectronic method (Fossomatic; Foss Electric, Hillerod, Denmark). Daily milk production of tested cows was measured using Waikato devices attached to milking machine. Each tube of milk samples was marked with ID number of cow and left at room temperature for 48 hours. After 48 hours, the solution was diluted with water and zinc was subsequently determined by inductively coupled plasma mass spectrometry (Perkin Elmer Elan 6100 ICPMS, Massachusetts, USA). Udder teat ends of were disinfected before and after milk samples were taken.

\section{RESULTS AND DISCUSSION}

Analyzing blood and milk serums samples of thirty Holstein cows zinc concentration varied as well as somatic cell count. Cows with zinc blood concentration higher then $13 \mu \mathrm{mol} / \mathrm{l}$ have low somatic cell count according to statistical correlation test (Figure 1). This negative correlation between zinc blood concentration and somatic cell count indicate significant zinc effect on somatic cell count. If zinc blood serum concentration is high, somatic cell count is low or if zinc blood serum concentration is low, somatic cell count is high.

According to statistical correlation test, there is no significant relation between zinc milk serum concentration and somatic cell count (Figure 2). The positive test correlation, indicate that cows with low zinc milk serum concentration have no difference in somatic cell count. Also, cows with high zinc milk serum concentration have no difference in somatic cell count.

Siciliano-Jones et al. (2008) reported no changes in milk composition and somatic cell count after supplemented dairy cows with organic source of $\mathrm{Zn}, \mathrm{Mn}, \mathrm{Cu}$ and Co. Griffiths et al. (2007) studied $\mathrm{Zn}, \mathrm{Mn}$ and $\mathrm{Cu}$ supplementation as an amino acid complex for grazing dairy cows, and 


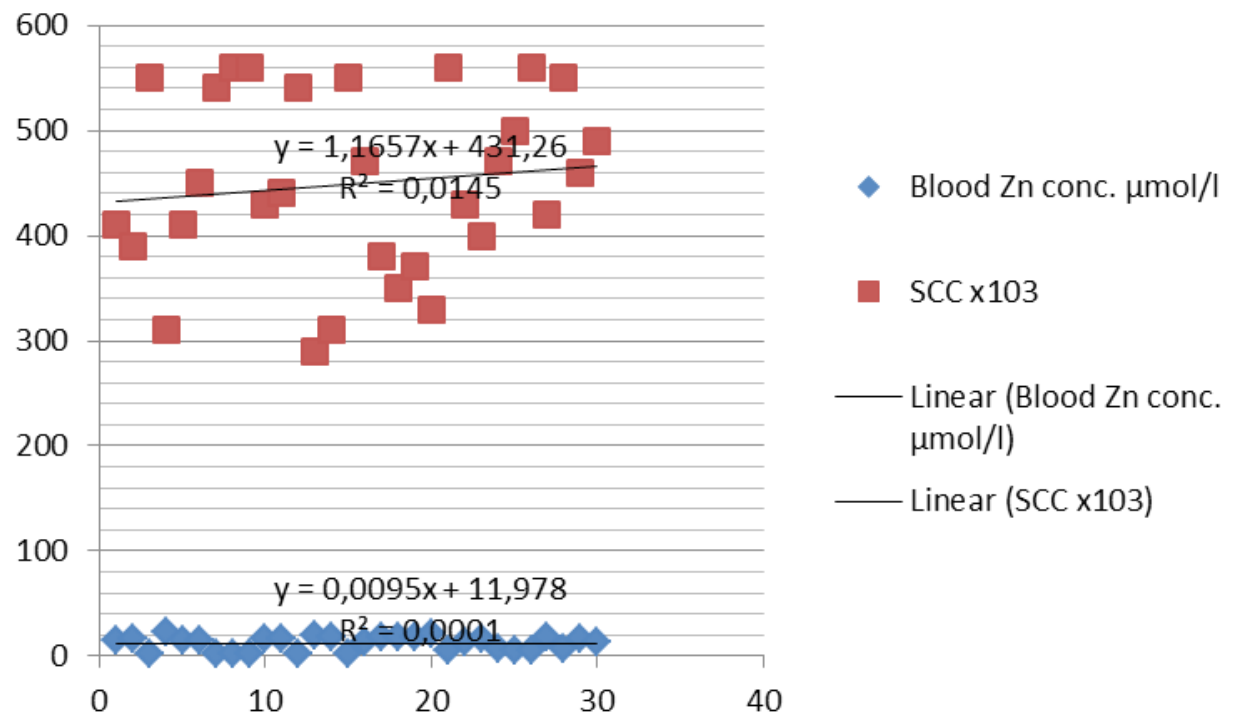

Fig. 1 Correlations between blood zinc serum concentration $(\mu \mathrm{mol} / \mathrm{l})$ and milk somatic cell count $\left(\mathrm{x} 10^{3} / \mathrm{ml}\right)$ in thirty Holstein dairy cows.

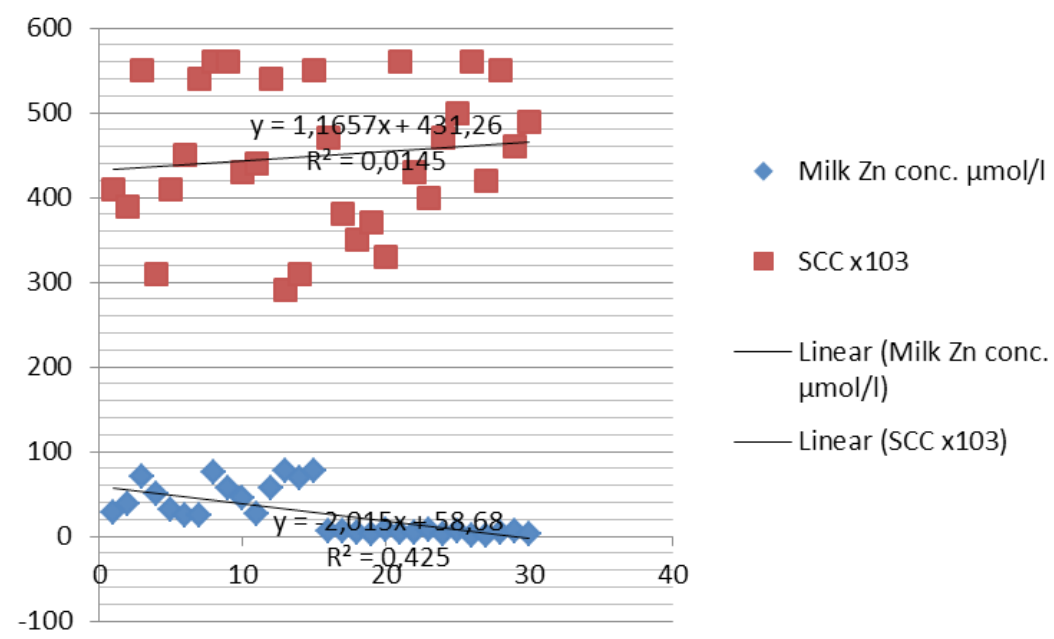

Fig. 2 Correlations between milk zinc serum concentration $(\mu \mathrm{mol} / \mathrm{l})$ and milk somatic cell count $\left(\mathrm{x} 10^{3} / \mathrm{ml}\right)$ in thirty Holstein dairy cows.

reported increased milk production, but no differences on somatic cell count. In contrast, Kinal et al. (2007) observed a reduction of somatic cell count with organic sources of $\mathrm{Zn}, \mathrm{Mn}$ and $\mathrm{Cu}$ supplementation in dairy cows during 305 days of lactation. Physiology level of zinc blood serum concentration is between $7-13 \mu \mathrm{mol} / \mathrm{l}$. Results in this research shows reduction somatic cell count and absence of subclinical mastitis in cows with zinc blood serum concentration higher then $13 \mu \mathrm{mol} / \mathrm{l}$. $37.67 \%(11 / 30)$ cows have zinc blood serum concentration below $7 \mu \mathrm{mol} / \mathrm{l}$, and $63.33 \%$
$(19 / 30)$ cows have zinc blood serum concentration higher then $13 \mu \mathrm{mol} / \mathrm{l}$. Also $30 \%$ (9/30) cows have somatic cell count lower then $400.000 / \mathrm{ml}$ which indicate absence of subclinical mastitis, but 70\% $(21 / 30)$ cows have somatic cell count higher than $400.000 / \mathrm{ml}$ which indicate subclinical mastitis. All cows with subclinical mastitis have milk serum zinc concentration between 1.02-77.38 $\mu \mathrm{mol} /$ and average value was $26.62 \mu \mathrm{mol} / \mathrm{l}$. Cows without subclinical mastitis milk serum zinc concentration was between 3.06-76.78 $\mu \mathrm{mol} / \mathrm{l}$ and average value was $29.37 \mu \mathrm{mol} / \mathrm{l}$. 


\section{CONCLUSION}

Cows with high zinc blood serum concentration have lower somatic cell count. Opposite cows with lower zinc blood serum concentration have high somatic cell count and high incidence of subclinical mastitis. According to results in this research there is no significant effect of milk serum zinc concentration on somatic cell count in dairy cows.

\section{REFERENCES}

1. Andieu S (2008). Is the role for organic trace element supplements in transition cow health? Vet J 176:77-83.

2. Barbano DM, Ma Y, Santos MV (2006). Influence of raw milk quality on fluid milk shelf life. J. Dairy Sci 89:15-19.

3. Blakeborough P, Salter DN, Gurr MI (1983). Zinc binding in cow`s milk and human milk. Biochem J 209:505-512.

4. Davidov I, Radinović M, Boboš S, Mašić Z, Lalošević D (2011). Effect of different thickness of keratin layer of ductus papillaris on state of parenchyma in cow udder. Veterinarski glasnik 65(5-6): 359-366.

5. Davidov I, Radinović M, Erdeljan M, Cincović M, Stančić I, Belić B (2013). Relations between blood zinc concentrations and udder health in dairy cows. Rev Med Vet 164(4):183-190.

6. Griffiths LM, Loeffler SH, Socha MT, Tomlinson DJ, Johnson AB (2007). Effects of supplementing complexed zinc, manganese, copper and cobalton lactation and reproductive performance of intensivly grazed lactating lactating dairy cattle on the South Island of New Zealand Anim Feed Sci Technol 137:69-83.
7. Kinal S, Korniewicz D, Jamroz A, Slupczynska M, Bodarski M, Zieminski R, Osieglowski S, Dymarski I (2007). The effectiveness of zinc, copper and manganese applied in organic forms in diets of high milk yielding cows. J Food Agric Environ 5:189-193.

8. Knowles SO, Grace ND, Knight TW, McNabb WC, Lee J (2006). Reasons and means for manipulating the micronutrient composition of milk from grazing dairy cattle. Anim Feed Sci Technol 131:154-167.

9. Paulrud CO (2005). Basic concept of the teat canal. Vet Res Comm 29:215-245.

10. Pechova A, Pavlata L, Dvorak R, Lokajova E (2008). Contents of $\mathrm{Zn}, \mathrm{Cu}, \mathrm{Mn}$ and Se in milk in relation to their concentration in blood, milk yield and stage of lactation in dairy cattle. Acta Vet Brno 77:523-531.

11. Siciliano-Jones JL, Socha MT, Tomlinson DJ, DeFrain JM (2008). Effect of trace mineral source on lactation performance, claw integrity and fertility of dairy cattle. J Dairy Sci 91:1985-1995.

12. Sharma N, Singh NK, Bhadwal MS (2011). Relationship of Somatic Cell Count and Mastitis: An Overview. Asian-Aust J Anim Sci 24(3): 429 - 438.

13. Spears JW, Weiss WP (2008). Role of antioxidants and trace elements in health and immunity of transition dairy cows. Vet J 176:70-76.

14. Underwood EJ (1977). Trace elements in human and animal nutriton. $4^{\text {th }}$ ed. Academic Press, New York, p.196242 .

15. Zadak K (2002). Zinek. In: Nutrition in intesive care. Granda Publishing, Praha, p.165-167. 